\title{
Growth and nutrition of Corymbia citriodora seedlings using doses of liquid swine waste
}

\author{
João Antônio da Silva Coelho', Cristiane Ramos Vieira², Oscarlina Lúcia dos Santos Weber'
}

\author{
1 Universidade Federal de Mato Grosso, Cuiabá, MT, Brazil. \\ 2. Universidade de Cuiabá, Cuiabá, MT, Brazil. \\ *Corresponding author, e-mail: cris00986@hotmail.com
}

\begin{abstract}
The experiment was installed in a greenhouse with the aimed to verify the influence of liquid swine waste in the development and nutrition of Corymbia citriodora seedlings. The swine waste was mixed with a commercial substrate in order to analyze the effects of five doses, in a randomized block design, considering the $\mathrm{N}$ requirement of the species, which were $\mathrm{T} 1-0 \%$; $\mathrm{T} 2-50 \%$; T3 100\%; T4 - 150\% and; T5 - 200\% and one treatment with mineral fertilization for comparison. The Corymbia citriodora seeds were germinated in plastic tubes with a commercial substrate plus swine waste. As the seedlings reached about five centimeters the thinning was performed, and when the plants reached $15 \mathrm{~cm}$ in length the growth analysis was started. At the end of the experiment the seedlings were measured, weighed and milled for macro and micronutrients determination. The best doses of liquid swine waste were $150 \%$ and $200 \%$ which showed the highest growth average values of the Corymbia citriodora seedlings, to the detriment of the nutritional and physical improvement of the substrate.
\end{abstract}

Keywords: Corymbia, organic waste, forestry nutrition

\section{Introduction}

Swine breeding in Brazil has increased in recent years due to the swine meat consumption, which is cheaper and thus more affordable for the population. Brazil is the 4th largest producer of swine, representing $10 \%$ of the total exported in the world (Map, 2013). However, this increase in swine production also promoted the increase of the waste, and its disposal may generate an increasingly aggravating environmental problem.

For many years, these wastes, called swine waste (SW), have been accumulated in natura, in landfills near watercourses, or simply deposited around the swine farming, compromising soil fertility due to the high concentration of nutrients

and heavy metals; or water quality because the swine waste can contaminate groundwater. Therefore, in the last years, some research has been dedicated to analyzing alternatives for the reuse of this waste. One of the most tested is its application in agriculture.

The swine waste improves soil physical properties such as soil aggregation, soil porosity, soil water retention and availability as mentioned by Agne \& Klein (2014) and Oliveira et al. (2015). However, this will depend on the volume added to the soil and on the current conditions of this waste and the soil itself, additionally, can be used as a substrate for the production of plant seedlings. Therefore, it is necessary to carry out 
studies to determine adequate doses for plants development. The wastewater (WW) or swine wastewater (SWW) may contain nutrients at levels toxic to plants, reach the water table, contain heavy metals (Condé et al., 2012), and pathogens, promote the sealing of soil micropores as a consequence of the soil compaction, or contain sodium in quantity to promote the dispersion of clay particles (Erthal et al., 2010; Homem et al., 2014).

Therefore, this research was carried out using Corymbia citriodora and SWW as a nutrient source. This species belongs to the family Myrtaceae and is native to Australia, but adapted to the Brazilian soils. According to Silva et al. (2009), the cultivation of this species in Brazil is mainly aimed at producing wood for various uses such as cross-ties, energy, charcoal and sawn wood. Among the forest species, it is one of the most cultivated by small and medium farmers in Minas Gerais and São Paulo states, for the production of essential oil, energy, and building. However, it presents a great diversity of uses, due to the characteristics of the wood and the production of essential oil, whose main constituent is citronella (Batish et al., 2006).

Thus, this study was conducted with the objective of evaluating the growth and nutrition of Corymbia citriodora seedlings submitted to increasing doses of swine waste under plant nursery conditions.

\section{Materials and Methods}

The experiment was carried out at Agronomy, Veterinary Medicine, and Animal Sciences School of the Universidade Federal de Mato Grosso. The greenhouse used for the study was constructed according to the following characteristics: milk-white shading material on the sides and covered with asbestos tiles, without temperature control.

A Corymbia citriodora seed lot from Dom Aquino county, Mato Grosso state, Brazil was used. The sowing was carried out in $170 \mathrm{~cm}^{3}$ tubes, previously sterilized with $1 \%$ sodium hypochlorite solution for five minutes. Then, the tubes were filled with a commercial substrate (Vivatto Slim Plus $\left.{ }^{\circledR}\right)$ constituted of biostabilized Pinus bark, vermiculite, pulverized charcoal, water and phenolic foam, which the characterization was determined using the Embrapa (1997) methodology (Table 1).

The SWW used in the experiment came from Piccini farm located in Lucas do Rio Verde County, Mato Grosso state, which uses the swine finishing system. The SWW was collected in a deposition lagoon and its chemical properties are described in Table 2.

Table 1. Substrate chemical properties

\begin{tabular}{|c|c|c|c|c|c|c|c|c|c|c|c|}
\hline $\mathrm{pH}$ & $\mathrm{H}+\mathrm{Al}$ & $\mathrm{Al}$ & $\mathrm{Ca}^{2+}$ & $\mathrm{Mg}^{2+}$ & $K$ & $\mathbf{P}$ & SB & CEC & $t$ & V & $\mathrm{m}$ \\
\hline $\mathrm{CaCl}_{2}$ & \multicolumn{4}{|c|}{---- $\mathrm{cmol}_{\mathrm{c}} \mathrm{dm}^{-3}$} & \multicolumn{2}{|c|}{-- $\mathrm{mg} \mathrm{dm}^{-3}--$} & \multicolumn{3}{|c|}{---- $\mathrm{cmol}_{\mathrm{c}} \mathrm{dm}^{-3}$----- } & \multicolumn{2}{|c|}{---- \% --- } \\
\hline 5.6 & 5.5 & 0.0 & 7.3 & 2.08 & 137.5 & 37.3 & 9.74 & 15.24 & 9.74 & 64 & 0.0 \\
\hline
\end{tabular}

Table 2. Swine waste chemical properties

\begin{tabular}{|c|c|c|c|c|c|}
\hline Boron (B) & Calcium (Ca) & Copper (Cu) & Sulfur (S) & Iron (Fe) & Phosphorus $\left(\mathrm{P}_{2} \mathrm{O}_{5}\right)$ \\
\hline \multicolumn{6}{|c|}{$\mathrm{mg} / \mathrm{L}$} \\
\hline 8.1 & 150.1 & 2.1 & 418.2 & 2.6 & 700.1 \\
\hline Magnesium (Mg) & Manganese (Mn) & Nitrogen $(\mathrm{N})$ & Potassium (K) & Sodium (Na) & Zinc $(Z n)$ \\
\hline \multicolumn{6}{|c|}{$\mathrm{mg} / \mathrm{L}$} \\
\hline 90.12 & 0.6 & 2100.4 & 400.2 & 210.1 & 1.2 \\
\hline
\end{tabular}

The sowing was performed using a transparent pen tube, adapted to drop few seeds in the tube. After sowing the germination occurred at 20 days. When the seedlings reached $5 \mathrm{~cm}$ height, was performed the thinning, leaving one seedling per container, the most central and robust one.

The experiment was carried out in a randomized block design: three blocks with six treatments (12 plants per block). The application of the SWW occurred after the thinning when the seedlings reached $10 \mathrm{~cm}$ height. The treatments 
used were $0,50,100,150$ and $200 \%$ of the $N$ requirement by the species and a treatment with mineral fertilization that considered the levels of $\mathrm{N}, \mathrm{P}$ and $\mathrm{K}$ in the waste. The SWW dose took into account the $\mathrm{N}$ levels, as this is the constituent with the highest relative concentration in the effluent. The application was made with a graduated syringes and followed the nutritional requirement suggested by Gonçalves and Benedetti (2000). Thus, the applied doses of SWW were 0 dose: 0 $\mathrm{mL}$ plant $^{-1}$; $50 \%$ dose: $5 \mathrm{~mL}^{\text {plant }}{ }^{-1}$; $100 \%$ dose: 10 $\mathrm{mL}$ plant $^{-1}$; $150 \%$ dose: $15 \mathrm{~mL}^{\text {plant }}{ }^{-1}$; $200 \%$ dose: $20 \mathrm{~mL}$ plant $^{-1}$.

For the mineral fertilization treatment, the N, P and K contents were taken to account the levels in the waste, remaining quantitatively equal to the $100 \%$ SWW treatment. The sources of $\mathrm{N}, \mathrm{P}$ and $\mathrm{K}$ were urea, potassium phosphate, and single superphosphate, respectively. The amount applied for each seedling in this treatment was $4.67 \mathrm{~g} \mathrm{~L}^{-1}$ urea, $1.026 \mathrm{~g} \mathrm{~L}^{-1}$ potassium phosphate and $1.91 \mathrm{~g} \mathrm{~L}^{-1}$ single superphosphate. The micronutrients available to the seedling was derived from the substrate and the SWW.

Nitrogen fertilizations with SWW and mineral fertilizer were performed every seven days from the 10th day after the thinning until the last day of growth analysis. In this way, six applications of SWW and mineral fertilization were carried out. During this period, irrigation occurred daily with an average water depth of five $\mathrm{mm}$, in the early morning and late afternoon, using a watering can.

Morphological characteristics were measured at the end of the study (75 days). The plant height was measured $(\mathrm{cm})$ with a graduated scale, from five centimeters from the soil surface to the apical bud. The plant neck diameter $(\mathrm{mm})$ was measured with a digital caliper. Afterward, they were sectioned in aerial part and root system, taken to a forced air oven at $65{ }^{\circ} \mathrm{C}$ until constant weight and, and then weighed to obtain the dry mass of the aerial part and of the root system. In order to evaluate the quality of the seedlings, the Dickson seedlings quality index (DQI), determined by the equation proposed by Dickson et al. (1960) was used.

The dry material was ground in a Wileytype mill to determine macro and micronutrient concentrations after sulfur and nitro-perchloric digestion, following the Malavolta et al. (1997) methodology.

The data were submitted to the analysis of variance and the comparison of means by the Tukey's test at the level of $5 \%$ and regression test, using the statistical software Assistat 7.6 beta, of UFCG, after verifying data normality.

\section{Results and Discussion}

Growth of Corymbia citriodora seedlings

The addition of SWW favored the plant height growing (Figure 1) of Corymbia citriodora seedlings, since the increase of the doses promoted a linear increase for this characteristic, with the highest average values at the $200 \%$ dose treatment. This is due to the addition of nutrients, mainly N and P (Faria et al., 2013), K, Ca, S and micronutrients (Trevisan et al., 2013; Krajeski \& Povaluk, 2014); organic matter (Caldeira et al., 2012), and the appropriate conditions of soil porosity (Caldeira et al., 2014).

The average value for height growth at the $200 \%(30.33 \mathrm{~cm})$ dose was $50 \%$ higher than the average values observed for the $0 \%$ treatment. Mineral fertilizer promoted an increase in growth of $2 \%$ compared to the treatment with $200 \%$, although it is the way to provide nutrients in adequate contents and in a shorter time. This proves that SWW can be used in the production of Corymbia citriodora seedlings. Batista et al. (2014) also demonstrated the influence of SWW on the height growth of Eucalyptus urophylla seedlings at $50 \%$ of SWW and attributed the results to the nutrient content, in addition to the favorable soil physical characteristics offered by SWW.

Oliveira et al. (2014) verified higher growth in height $(10.85 \mathrm{~cm})$ of Corymbia citriodora seedlings in $25 \%$ of carbonized rice husk $+75 \%$ of vermiculite. Steffen et al. (2011) found an average value of $14 \mathrm{~cm}$ for plant height using $80 \%$ of vermicompost $+20 \%$ of peat, whereas Bernardi et al. (2012) observed the average growth of up to $16.42 \mathrm{~cm}$ in the treatment with hydrogel $+80 \%$ of a slow-realise fertilizer (19-6-10). All these results were lower than those found in the present study. 

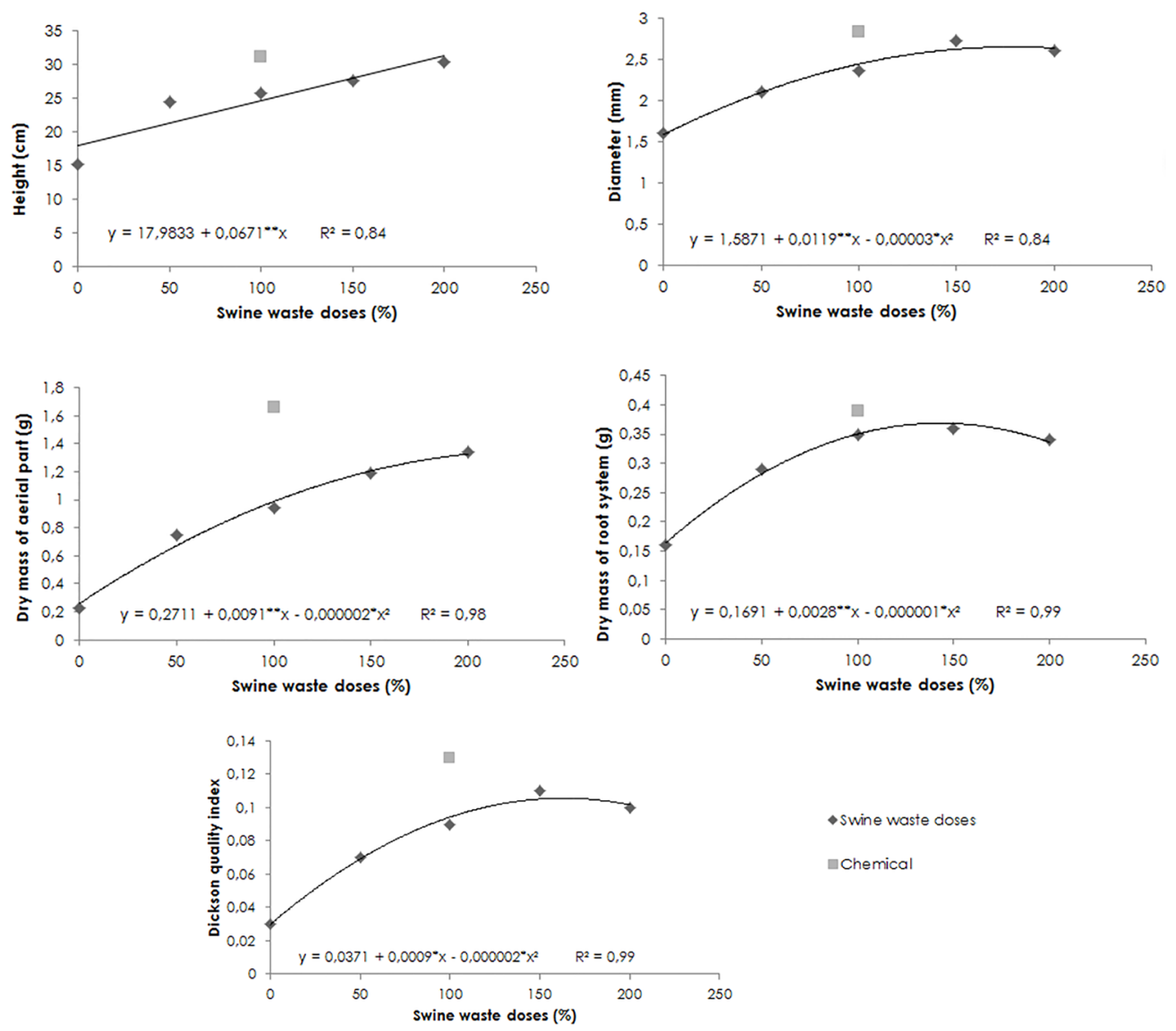

- Swine waste doses

Echemical

Figure 1. The regression equations for height $(\mathrm{cm})$, diameter $(\mathrm{mm})$, dry mass of aerial part and root system (g) and Dickson quality index on Corymbia citriodora seedlings.

The SWW doses also influenced the growth in diameter, demonstrating the adequate initial development of the species in the enriched substrate. The growth in diameter occurred in a quadratic model during the 75 days, reaching average values of $2.7 \mathrm{~mm}$ and $2.6 \mathrm{~mm}$ at the $150 \%$ and $200 \%$ doses, respectively. These average values were $40.7 \%$ and $38.5 \%$ higher in the abovementioned doses, in relation to the $0 \%$ dose and; $3 \%$ and $7 \%$ lower than the average values observed for the treatment with mineral fertilization. According to Trazzi et al. (2014), this growth is due to the higher soil water retention capacity and low soil microporosity, improving the efficiency of water and nutrients supply, mainly $\mathrm{K}$.

Oliveira et al. (2014) observed growth in diameter of $1.4 \mathrm{~mm}$ in Corymbia citriodora seedlings cultivated in $25 \%$ of carbonized rice husk $+75 \%$ vermiculite. Bernardi et al. (2012) verified a diameter average value of $2.29 \mathrm{~mm}$ in treatment with hydrogel $+80 \%$ of slow-release fertilizer (19-6-10). Lopes et al. (2015) found an average value of $2.28 \mathrm{~mm}$ in the substrate containing biostabilized sugarcane bagasse and pulverized charcoal (8/2 v: v). Results lower than those observed in the $100 \%, 150 \%$ and $200 \%$ doses in the present study.

As recommended by Xavier et al. (2009), in order to plant Corymbia citriodora seedlings in field, the height should be between 20 to $40 \mathrm{~cm}$ and $2 \mathrm{~mm}$ diameter, thus, it is emphasized that the addition of SWW provided these conditions, because only at the $0 \%$ dose these average values were not reached.

Therefore, the applications of SWW had a positive influence on growth in height and diameter of Corymbia citriodora. However, since SWW is to be used in combination with another material, must also pay attention to the characteristics of the added materials so that if there is no incompatibility. In the present case, the commercial substrate used was favorable to the seedling growing. 
The growth in plant height influenced the dry mass production in the aerial part of the Corymbia citriodora seedlings, showing a quadratic response as a function of the SWW application. The highest average values were found at the $200 \%$ dose, with $1.34 \mathrm{~g}$, which was $83 \%$ higher than the $0 \%$ dose treatment and; $19 \%$ lower than the mineral fertilization treatment.

Foliar mass production is one of the characteristics related to the survival of the species in the field. In this case, the seedlings of the $200 \%$ swine waste treatment would be the most suitable for planting, reinforcing the previous results, which, according to Trazzi et al. (2014) can be attributed to the physical and chemical properties provided by the waste. These results at the $200 \%$ dose for the aerial part were higher than those obtained by Lopes et al. (2015) for Corymbia citriodora seedlings produced from bioremediate cane bagasse and pulverized charcoal (8/2 v: v), whose average value was $1.34 \mathrm{~g}$ and by Steffen et al. (2011) in seedlings produced with $80 \%$ vermicompost $+20 \%$ peat, with an average value of $0.2 \mathrm{~g}$.

The dry mass production of the roots was similar to the leaf mass production, with average values equal to $0.36 \mathrm{~g}$ at the $150 \%$ doses and 0.34 $g$ at the $200 \%$ dose, which were $55 \%$ and $53 \%$ higher than the average values obtained for the $0 \%$ dose treatment, respectively. In comparison with the mineral fertilization, the average values were $7.7 \%$ higher than the $150 \%$ dose and; $12.8 \%$ higher than the $200 \%$ dose, showing a quadratic response for this characteristic. This mass production in the root system is important because it influences the absorption of water and nutrients. Plants with a well-developed root system can achieve a larger substrate volume and absorb nutrients in adequate levels to the species needs.

The Dickson quality index (DQI) data also showed a quadratic effect as a function of the SWW doses, with the highest average values at the $150 \%$ and $200 \%$ doses. Similar to the results observed for the mineral fertilization, which was $15 \%$ higher than the $150 \%$ dose and $23 \%$ higher than the $200 \%$ dose.

Therefore, the use of SWW in the production of Corymbia citriodora seedlings is a viable alternative since it contributes to the nutrition of the seedlings and, consequently, conferred a faster growth, thus, considering all characteristics analyzed the recommended doses should be $150 \%$ and $200 \%$ doses.

\section{Macronutrient levels in the Corymbia citriodora} seedlings

The macronutrient levels in the leaves of Corymbia citriodora seedlings were influenced by the addition of SWW, to the detriment of the improvement in nutrient conditions of the substrate (Figures 2 and 3). However, adequate levels of $\mathrm{K}, \mathrm{Ca}$ and $\mathrm{Mg}$ were not observed, as recommended by Malavolta et al. (1997) for forest species. This can be justified by the levels of $\mathrm{K}, \mathrm{Ca}$ and $\mathrm{Mg}$ present in the SWW treatments, but this did not limit growth.

The $\mathrm{N}$ content (Figure 2) showed an increasing trend in relation to the SWW doses, obtaining a linear equation. The average values were within the range recommended by Malavolta et al. (1997), which is from 12 to $35 \mathrm{~g}$ $\mathrm{kg}^{-1}$, only at the $150 \%$ and $200 \%$ doses and the mineral fertilization. These results indicate the plant need for $\mathrm{N}$, which is one of the essential elements required since it is part of important reactions in the plant such as photosynthesis, ionic absorption, protein synthesis, among others (Malavolta et al., 1997). This is because the $\mathrm{N}$ levels present in the commercial substrate and in SWW were sufficient to maintain the seedlings grown in these treatments, without the necessity of complementary fertilization.

The average values for $\mathrm{P}$ content (Figure 2) showed a decreasing quadratic tendency stem from the $100 \%$ dose, with the lowest values at the $0 \%$ dose. However, these levels were higher than those recommended by Malavolta et al. (1997), which is from 1.0 to $2.3 \mathrm{~g} \mathrm{~kg}^{-1}$, increasing the SWW doses. It was verified that SWW was efficient in providing $P$, which may be related to the improvement of soil fertility conditions. Swine waste may works as a neutralizer of the soil acidity since it increases the nutrient content and the basis saturation, consequently, it increases the $\mathrm{pH}$ values and reduces the levels of Al, making the $\mathrm{P}$ content available. Thus, this contributes to plant growth, since $P$ is related to the production 
of cellular energy, the photosynthetic process, and storage. This was confirmed by Santos et al. (2008) who verified that, when increasing the supply of $P$, there were increases in dry mass production, proving that the swine waste has a higher amount of $P$ in its constitution. In addition to these characteristics, $P$ is also associated with the greater development of the root system (Rocha et al., 2013). A well-developed root system facilitates the $\mathrm{P}$ absorption, which occurs by diffusion, aiding in the growth of the plant.

The highest $S$ content (Figure 3) were observed in the $150 \%$ dose and were adjusted to the decreasing quadratic model, with adequate averages at the 100\%, 150\%, 200\% doses and mineral fertilization treatment, according to Malavolta et al. (1997). Therefore, the S content present in the SWW and the commercial substrate were sufficient to maintain the growth of Corymbia citriodora seedlings.
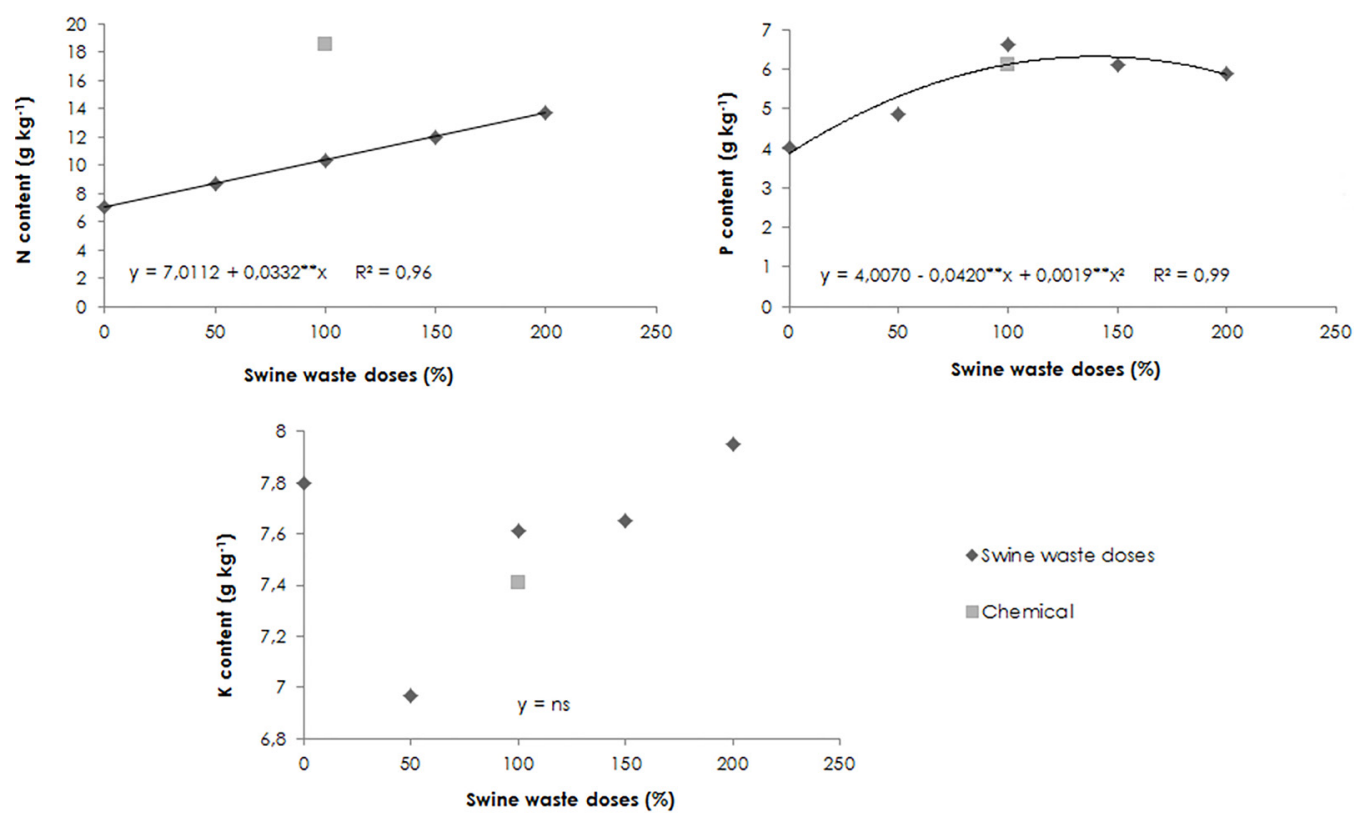

Figure 2. The regression equations for $\mathrm{N}, \mathrm{P}$ and $\mathrm{K}$ contents in leaves of Corymbia citriodora.

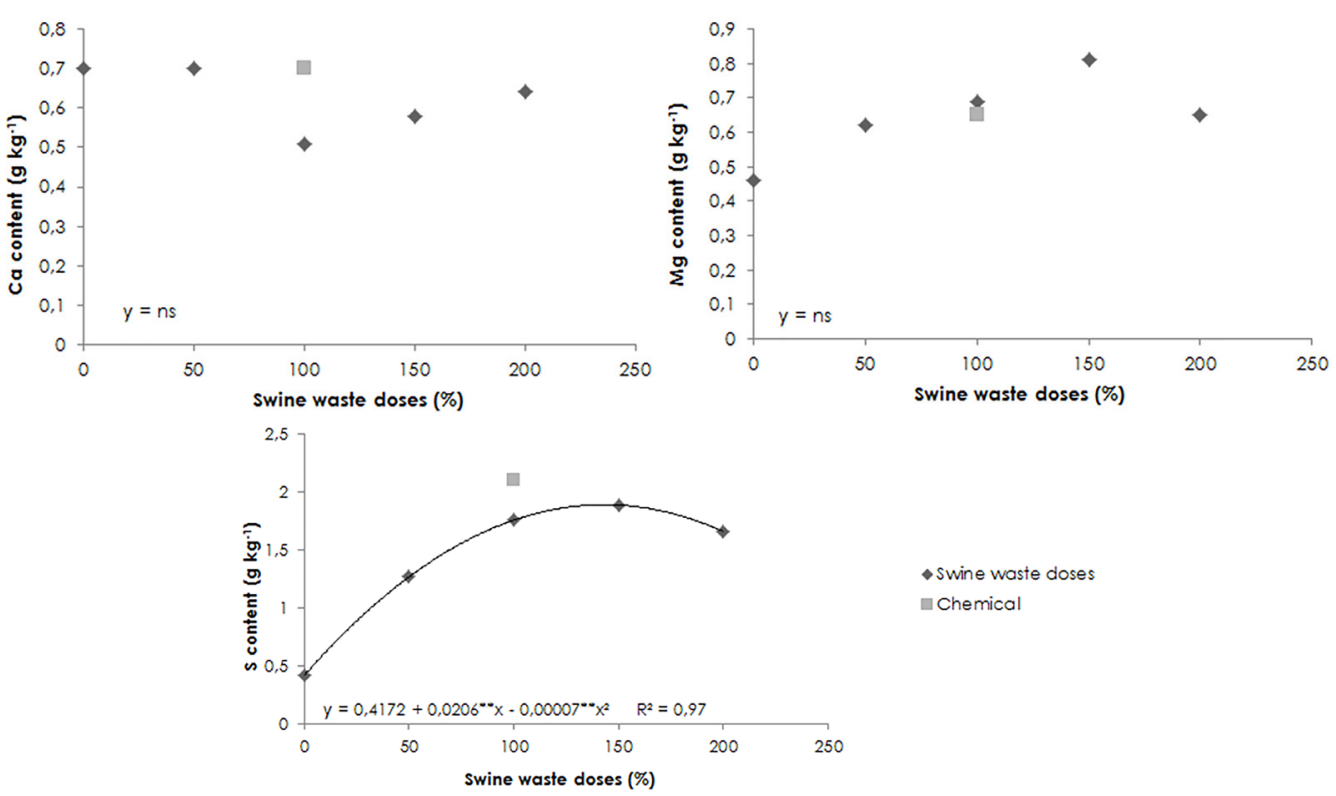

Figure 3. The regression equations for $\mathrm{Ca}, \mathrm{Mg}$ and $\mathrm{S}$ contents in leaves of Corymbia citriodora. 
Therefore, the macronutrient levels in the SWW will depend on the composition of the material, its origin, and the process until it becomes suitable for use as a substrate in the seedlings production. In addition, the results obtained will also depend on the nutritional requirements of the species over its growth. This may explain the low levels of $\mathrm{K}, \mathrm{Ca}$ and $\mathrm{Mg}$ in leaves of Corymbia citriodora.

Micronutrient levels in the Corymbia citriodora seedlings

The micronutrient contents in Corymbia citriodora are shown in Figures 4 and 5. Fe content were not significant, however, adequate levels were observed in all treatments, with the highest
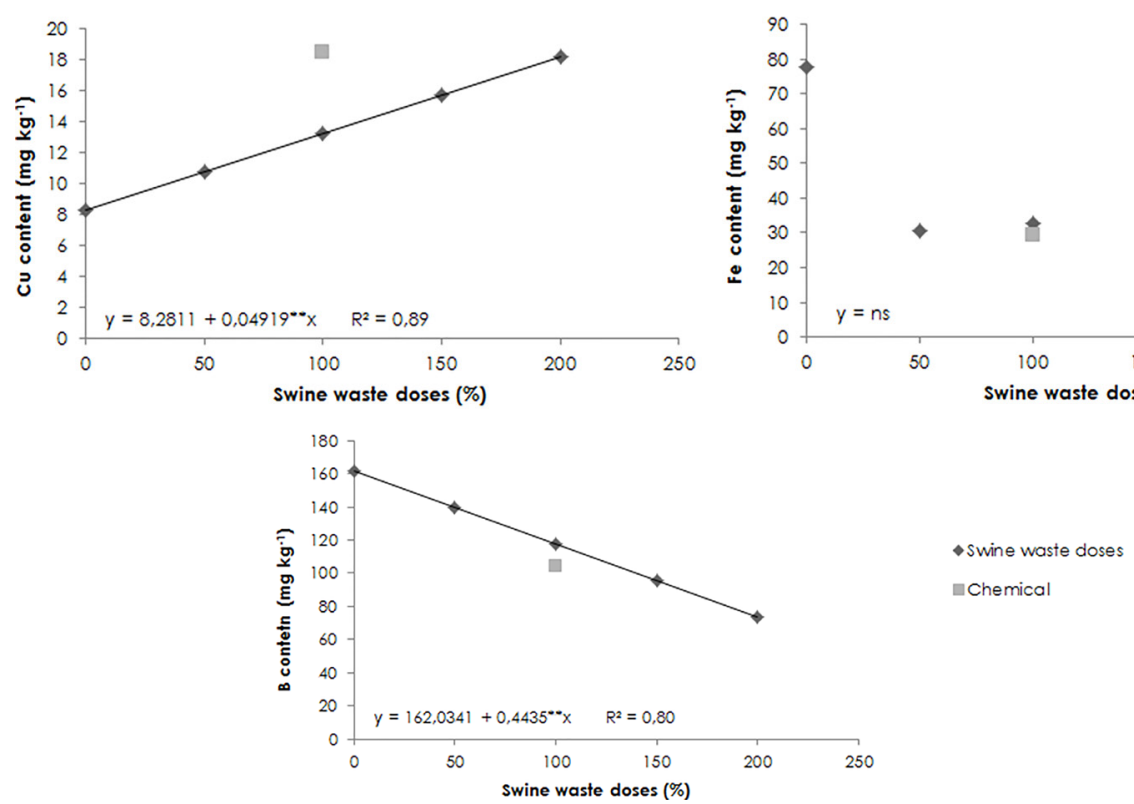

Figure 4. The regression equations for $\mathrm{CU}, \mathrm{Fe}$ and $\mathrm{B}$ contents in leaves of Corymbia citriodora.

The B contents (Figure 4) data were adjusted to a decreasing linear model, therefore, the SWW likely has a lower B content than those found in the commercial substrate, which could limit B levels in the plant and, consequently, its growth. However, all treatments provided B levels greater than the adequate levels, since, Malavolta et al. (1997) recommended up to $20 \mathrm{mg} \mathrm{kg}^{-1}$ and the average values for this characteristic in the present study ranged from $73 \mathrm{mg} \mathrm{kg}^{-1}$ at the $200 \%$ dose to $162 \mathrm{mg} \mathrm{kg}^{-1}$ at the $0 \%$ dose.

Regarding the Mn contents (Figure 5), data were adjusted to a decreasing linear model, and the highest average values were found average values at the $0 \%$ dose. This occurred probably due to the Fe content present in the commercial substrate. At the $100 \%$ dose, the results were similar to those obtained in mineral fertilization. Important results for total plant growth.

The Cu content (Figure 4) data as a function of the SWW doses was adjusted to a linear increasing model. This implies that the contents of this micronutrient in the substrate and SWW increased the levels in the leaves of Corymbia citriodora, contributing to its growth. Thus, only at the $0 \%$ dose was not observed adequate Cu levels, according to Malavolta et al. (1997), which should be between 10 and 70 $\mathrm{mg} \mathrm{kg}^{-1}$.

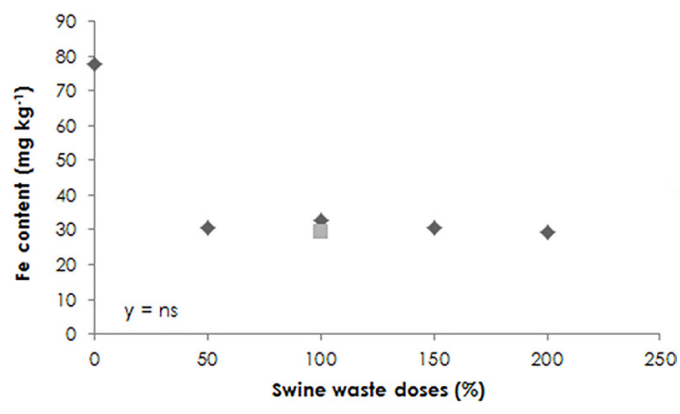

in the plants submitted to mineral fertilization. However, these average values were within the adequate range according to Malavolta et al. (1997) in all treatments. This result contributed to the growth of Corymbia citriodora seedlings in the SWW treatments.

The addition of SWW also increased the Zn levels (Figure 5), showing a quadratic regression, with the lowest average value $\left(34 \mathrm{mg} \mathrm{kg}^{-1}\right)$ at the $0 \%$ dose and; the highest one at the $200 \%$ dose $\left(71 \mathrm{mg} \mathrm{kg}^{-1}\right)$ and in the mineral fertilization (93 $\mathrm{mg} \mathrm{kg}^{-1}$ ). However, all these treatments showed micronutrient levels lower than those recommended by Malavolta et al. (1997). These results proved that SWW can contribute to 

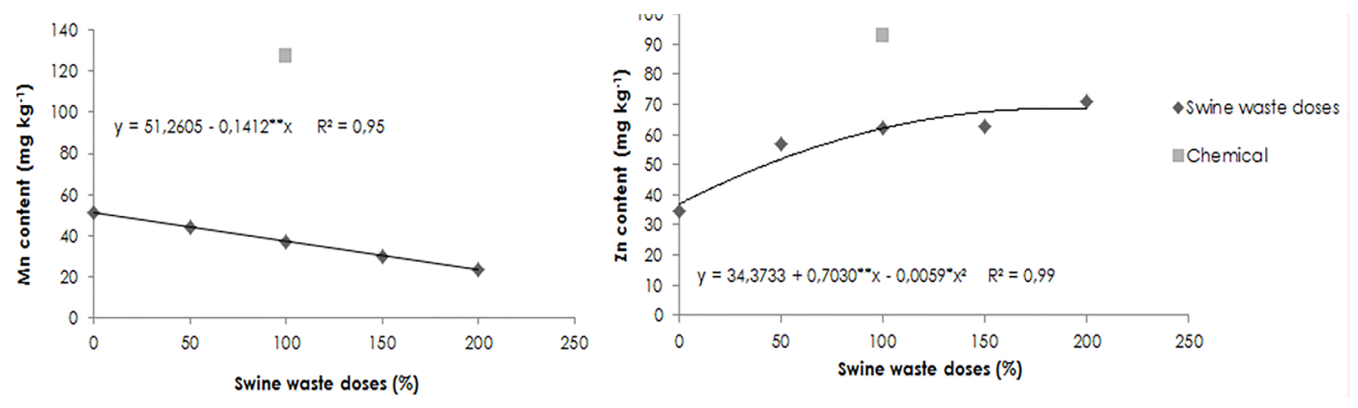

Figure 5. The regression equations for $\mathrm{Mn}$ and $\mathrm{Zn}$ contents in leaves of Corymbia citriodora.

the plant nutrition, helping the plants to grow. However, the combinations should be observed, since these can lead to increase nutrient levels to toxic levels.

\section{Conclusions}

a) The best doses of SWW were $150 \%$ and $200 \%$ which allowed the highest growth rates of Corymbia citriodora seedlings, to the detriment of nutritional and physical conditions. However, considering that the producer seeks the smallest investment in the seedlings production, it is recommended to use commercial substrate Vivatto Slim Plus ${ }^{\circledR}$ plus $150 \%$ of swine waste.

b) The Corymbia citriodora seedlings on the commercial substrate with SWW did not show adequate levels of $\mathrm{K}, \mathrm{Ca}, \mathrm{Mg}$ and $\mathrm{Fe}$. However, neither symptoms of deficiency and nor reduction in growth were observed.

\section{References}

Agne, S.A.A., Klein, V.A. 2014. Matéria orgânica e atributos físicos de um Latossolo Vermelho após aplicações de dejeto de suínos. Revista Brasileira de Engenharia Agrícola e Ambiental 18: 720-726.

Batish, D.R., Singh, H.P., Kaur, S., Kohli, R.K. 2006. Chemical composition and phytotoxicity of volatile essential oil from intact and fallen leaves of Eucalyptus citriodora. Zeitschriftfur Naturforschung - Section C 61: 465-471.

Batista, R.O., Martinez, M.A., Paiva, H.N., Batista, R.O., Cecon, P.R. 2014. O efeito da água residuária da suinocultura no desenvolvimento qualidade de mudas de Eucalyptus urophylla. Ciência Florestal 24: 127-135.

Bernardi, M.R., Sperotto Junior, M., Daniel, O., Vitorino, A.C.T. 2012. Crescimento de mudas de Corymbia citriodora em função do uso de hidrogel e adubação. Cerne 18: 67-74.

Caldeira, M.V.W., Gomes, D.R., Gonçalves, E.O.,
Delarmelina, W.M., Sperandio, H.V., Trazzi, P.A. 2012. Biossólido como substrato para produção de mudas de Toona ciliata var. australis. Revista Árvore 36: 1009-1017.

Caldeira, M.V.W., Favalessa, M., Gonçalves, E.O., Delarmelina, W.M., Santos, F.E.V., Viera, M. 2014. Lodo de esgoto como componente de substrato para produção de mudas de Acacia mangium Wild. Comunicata Scientiae 5: 34-43.

Condé, M.S., Homem, B.G.C., Almeida Neto, O.B., Santiago, A.M.F. 2012. Influência da aplicação de águas residuárias de criatórios de animais no solo: atributos químicos e físicos. Revista Brasileira de Agropecuária Sustentável 2: 99-106.

Dickson, A., Leaf, A.L., Hosner, J.F. 1960. Quality appraisal of white spruce and white pine seedlings stock in nurseries. Forest Chronicle 36: 10-13.

Empresa Brasileira de Pesquisa Agropecuária - EMBRAPA. 1997. Serviço Nacional de Levantamento e Conservação de Solos. Manual de métodos de análise do solo. 2.ed. Rio de Janeiro, Embrapa. 212 p.

Erthal, V.J.T., Ferreira, P.A., Matos, A.T., Pereira, O.G. 2010. Alterações físicas e químicas de um Argissolo pela aplicação de água residuária de bovinocultura. Revista Brasileira de Engenharia Agrícola e Ambiental 14: 467-477.

Faria, J.C.T., Caldeira, M.V.W., Delarmelina, W.M., Lacerda, L.C., Gonçaves, E.O. 2013. Substratos à base de lodo de esgoto na produção de mudas de Senna alata. Comunicata Scientiae 4: 342351.

Gonçalves, J.L.M., Benedetti, V. 2000. Nutrição e fertilização florestal. Piracicaba, IPEF. 427 p.

Homem, B.G.C., Almeida Neto, O.B., Condé, M.S., Silva, M.D., Ferreira, I.M. 2014. Efeito do uso prolongado de água residuária da suinocultura sobre as propriedades químicas e físicas de um Latossolo Vermelho-Amarelo. Científica 42: 299309. 
Krajeski, A., Povaluk, M. 2014. Alterações no solo ocasionadas pela fertirrigação dos dejetos suínos. Saúde e Meio Ambiente 3: 3-18.

Lopes, E.D., Soares, V.B., Silva, L.R. 2015. Utilização de resíduos agroflorestais na formulação de substrato renovável para produção de mudas de Corymbia citriodora. Caderno de Ciências Agrárias 7: 138-148.

Malavolta, E., Vitti, G.C., Oliveira, S.A. 1997. Avaliação do estado nutricional das plantas: princípios e aplicações. 2.ed. Piracicaba, Potafos. 319 p.

Mapa - Ministério da Agricultura, Pecuária e Abastecimento. 2013. Suínos. http://www. agricultura.gov.br/animal/especies/suinos. <Acesso em 14 fev. 2015>

Oliveira, K.F., Souza, A.M., Sousa, G.T.O., Costa, A.L.M., Freitas, M.L.M. 2014. Estabelecimento de mudas de Eucalyptus spp. e Corymbia citriodora em diferentes substratos. Floresta e Ambiente 21 : 30-36.

Oliveira, D.M.S., Lima, R.P, Verburg, E.E.J. 2015. Qualidade física do solo sob diferentes sistemas de manejo e aplicação de dejeto líquido suíno. Revista Brasileira de Engenharia Agrícola e Ambiental, 19: 280-285.

Rocha, J.H.T., Backes, C., Diogo, F.A., Pascotto, C.B., Borelli, K. 2013. Composto de lodo de esgoto com substrato para mudas de eucalipto. Pesquisa Florestal Brasileira 33: 27-36.

Santos, J.Z.L., Resende, A.V., Furtini Neto, A.E., Corte, E.F. 2008. Crescimento, acúmulo de fósforo e frações fosfatadas em mudas de sete espécies arbóreas nativas. Revista Árvore 32: 799-807.

Silva, P.H.M.; Poggiani, F.; Stape, J.L.; Brito, J.O.; Moreira, R.M. 2009. Produção de óleo essencial e balanço nutricional em Corymbia citriodora adubado com lodo de esgoto em diferentes espaçamentos. Cerne 15:346-354.

Steffen, G.P., Antoniolli, Z.I., Steffen, R.B., Schiedeck, G. 2011 . Utilização de vermicomposto como substrato na produção de mudas de Eucalyptus grandis e Corymbia citriodora. Pesquisa Florestal Brasileira 31: 75-82.

Trazzi, P.A., Caldeira, M.V.W., Reis, E.F., Silva, A.G. 2014. Produção de mudas de Tectona grandis em substratos formulados com biossólido. Cerne 20: 293-302.

Trevisan, A.P., Freitas, P.S.L., Rezende, R., Silvano, C., Faria Junior, C.A. 2013. Atributos químicos do solo e qualidade do percolado com aplicação de água residuária de suinocultura. Enciclopédia Biosfera 9: 2687-2697.
Xavier, A., Wendling, I., SILVA, R.L. 2009. Silvicultura clonal: princípios e técnicas. Viçosa, UFV, 2009. $272 \mathrm{p}$. 